\title{
From Oviparity to Marsupialism: Strange Modes of Reproduction in Amphibians
}

\section{Exbrayat JM* \\ Laboratory of General Biology, Lyon Catholic University, France}

*Corresponding author: Jean-Marie Exbrayat, Lyon Catholic University, UDL - EPHE, PSL, 10 Place des Archives, F-69288 Lyon Cedex 02, France, Email: jmexbrayat@univcatholyon.fr

\section{Mini Review}

Volume 1 Issue 2

Received Date: May 24, 2018

Published Date: June 04, 2018

\section{Abstract}

Amphibians are among the first vertebrates that have conquered the terrestrial environment. Their way of life is characterized by a compulsory aquatic larval phase and an adult terrestrial phase separated by a metamorphosis. Amphibians remain subservient to the aquatic environment throughout their lives. Several adaptive mechanisms regarding reproductive patterns have been established during biological evolution. Some species are oviparous; others are viviparous or direct-developing. Fertilization can be external or internal. Alongside these conventional breeding methods, some amphibians have developed particular forms of marsupialism or transport of eggs and larvae allowing them to at least partially free themselves from the aquatic environment.

Keywords: Amphibian; Anuran; Urodelan; Gymnophionan; Caecilian; Reproductive Cycle; Oviparity; Viviparity; Direct Development; Marsupialism; Phoresy

\section{Introduction}

Intermediaries between fish and reptiles, the amphibians are among the first vertebrates that have conquered the terrestrial environment. Their way of life is characterized by a compulsory aquatic larval phase and an adult terrestrial phase separated by a metamorphosis already described by Aristotle (384-322 BC).Some species remain aquatic or return to the aquatic life in the adult state. Amphibians are found on five continents, in temperate and tropical areas, and in the oases in semiarid and arid areas. Adaptive mechanisms regarding reproductive patterns have been established during biological evolution.
The interests in studying these animals are multiple. Living first in an aquatic and then terrestrial environment, amphibians are used as models to understand adaptations to the environment. Undergoing a metamorphosis, a drastic phase of their life with a very profound change in physiology and morphology, amphibians are particularly sensitive to the environment, becoming bio-indicators of its quality. It is therefore useful to know their biology to protect them. Amphibians have long been useful for acquiring scientific knowledge. Claude Bernard (1813-1878) or Dubois-Reymond (18181896) used frogs to understand various physiological phenomena. Amphibians were also useful to understand the mechanism of embryonic development [1] and more 


\section{International Journal of Zoology and Animal Biology}

particularly to understand the importance of the apoptosis during this development [2]. The first transplants of blastula cell nuclei to enucleated eggs were performed in amphibians [3]. These animals are also useful models for testing ecotoxicological effects of chemicals [4]. Amphibians are also of interest to the pharmaceutical industry because their skin develops antibiotic molecules or opioid with greater effects than the same molecules found in mammals $[5,6]$.

Amphibians are divided into three orders: Anurans, with frogs, toads and tree-frogs, Urodelans with salamanders and newts, and Caecilians or Gymnophionans, which are burrowing lengthened animals living in tropical areas.

\section{Reproductive Cycles}

Since amphibians are ectothermic animals, reproduction is closely linked to seasonal variations, and under endocrinal regulation [7,8]. In temperate-zone, Anura and Urodela reproductive cycles are mainly related to temperature changes, with reproduction occurring in the spring. In tropical areas, reproduction is related to both temperature and mainly precipitation, with animals having a predominantly discontinuous reproductive cycle. In some cases, egg-laying occurs when the weather is rainy, during the monsoon for example. In areas with highly variable seasons, with irregular rains in some semi-arid areas of Africa, males and female genitals are always ready to breed when conditions become favorable (mating of males and females in temporary ponds water). There are also exceptional breeding modes, not especially seasonal, but allowing the animals to be released from the aquatic environment: this is the case in some tropical species that have adopted original forms of development such as marsupialism or intraoral incubation. This is also the case for amphibians living in frozen soils that reproduce in a short time when the soil is thawed.

In the anurans, breeding cycles are always seasonal [911]. In certain species, the cycles of males are characterized by a discontinuous spermatogenesis. In this case, the testes are filled with germ cells until they are empty at the time of reproduction, then the testes can wait until the next breeding season to be filled again. It is the case of Nimbaphrynoides (formerly Nectophrynoides) occidentalis, African toad of the Nimba Mountains in Ivory Coast. In contrast, the testes of certain species can be filled well before the breeding season and the germ cells then remain stored until the reproduction, like in Rana temporaria of temperate countries. In species with continuous spermatogenesis, all types of germ cells are present at the same time: this is the case of many African toads such as Sclerophrys (formerly Amietophrynus or Bufo) regularis (Togo, Congo), Phrynobatrachus calcaratus (Ivory Coast), Xenopus laevis (South Africa), Sclerophrys (formerly Amietophrynus or Bufo) mauritanicus of the Algerian coast $[12,13]$. These last animals are ready to breed as soon as the weather conditions are favorable. Some cycles are potentially continuous. After spawning, spermatogenesis is observed several times but they do not terminate and spermatozoa do not form: it is necessary to wait until the correct season for spermatogenesis to be complete and reproduction can then take place. This is the case found in the complex of the green frog Pelophylax kl. esculentus (formerly Rana esculenta) [14-16].

The cycles of the females are super imposable to those of the males. In African species with continuous cycles, the ovaries contain a constant number of follicles at all stages of evolution throughout the year. As soon as external conditions allow, males and females are ready to breed. This is the case of Sclerophrys mauritanicus, $S$. regularis, and Phrynobatrachus calcaratus [17].

In some urodelans, the male cycles are discontinuous (Hynobius sp., Plethodoncinereus). In some cases, spermatozoa are stored in the vas deferens until the reproduction period. A new spermatogenesis can then be noted (Gyrinophilus porphyriticus). In Taricha torosa (Triturus torosus) and Notopohtalmus viridescens (Triturus viridescens), spermatozoa are evacuated between September and May in several waves. They accumulate in Wolffian ducts and breeding occurs in April-May. In European male salamanders, the number of testicular lobes increases with age. The lobes of the anterior region contain the earliest stages and more the lobes are posterior, more the germ cells they contain are in advanced stages. The last lobes are empty because they were evacuated the previous year. During the breeding season, the male lays a spermatophore on the soil that is seized by the cloaca of the female. There is indirect internal fertilization. The European Salamandra salamandra is oviparous in plain, but at altitude, it keeps embryos for a longer or shorter time in their uterus. In these species, the cycle is annual. In $S$. fastuosa, a closely related species, the cycle is biennial at $1000 \mathrm{~m}$ altitude [8]. In the salamander of the Alps, Salamandra atra, the duration of the gestation varies according to the altitude: 2 years at $650 \mathrm{~m}, 4$ to 5 years between 1700 and $1850 \mathrm{~m}$ [18]. A similar type of cycle is found in Salamandra lanzai $[19,20]$. Mertensiella and the Siberian Salamandrella have annual cycles with variations in reproductive patterns depending on the environment [21-24]. 


\section{International Journal of Zoology and Animal Biology}

The males of the caecilians are equipped with a copulatory organ, the phallodeum. They have a pair of segmented testes, each lobe of which being divided into seminiferous lobules a pair of Müller's glands acts as a prostate [25-30]. Breeding cycles are usually discontinuous and annual [30]. In females, the cycles may be different. The female cycle of Typhlonectes compressicauda is biennial even if the gestation lasts only 6 or 7 months [31,32]. The same type of cycle is observed in Gymnopis multiplicata (Costa Rica), Dermophis mexicanus (Guatemala) [33]. In Africa, the sexual cycle of Boulengerula taitanus males (Kenya) is continuous. The female cycle is annual with spawning during a rainy season, from July to November [34,35]. Eggs contain already developed embryos [36].

\section{Fertilization}

In anurans living in temperate countries, at the exit of hibernation, females and males migrate to their breeding grounds where they unite in amplexus. The female emits oocytes which are fertilized with sperm emitted by the male. Fertilization is external excepted in the tailed frogs (Ascaphidae), Nimbaphrynoides (Nectophrynoides) occidentalis, and Limnonectes larvaepartus [10,11,37].

At spring, male and female salamanders head to the spawning grounds where complex courtship parades bring the sexes together. When fertilization is external (Cryptobranchidae and Hynobiidae), spawning takes place in water, females emit oocytes that males fertilize. Fertilization is internal in Ambystomatidae (Euproctes), Salamandridae (Pleurodeles, Salamandrina, Notopohtalmus, Taricha). In these families, the males approach females and engage on a courtship with or without amplexus. The male deposit a spermatophore that the female takes with its cloaca in order to fertilize oocytes $[10,11]$.

In all the caecilians, fertilization is internal. The copulation can last several hours. Caecilian species can be oviparous, viviparous or in direct development, and early development occurs in the female genital tract $[27,38,39]$.

\section{Phoresy}

In Alytes obstetricans, the midwife toad, the male carries the eggs around his thighs, from laying to hatching [10] In other species, eggs are laid on the ground and the tadpoles are transported on the backs of their parents $[37,40]$. The phoresy can be temporary and the larvae then complete their development on land (Dendrobates,
Phyllobates). Phoresy may also be definitive until the end of development (Sooglossus sechellensis). In Amphignatodontidae such as Stefania evansi and Hemiphractinae such as Hemiphractus bribalus, eggs are carried by the mother and housed on the maternal dorsal coat. The gills are hypertrophied and increase the respiratory surface in contact with the air. In Fritzinia goeldi (Brazil), the eggs are located into the skin of the back which protects the larvae [37].

\section{Marsupialism and Incubation in a Natural Cavity}

In several species, the incubation of eggs and development lead to the development of integumentary structures to protect eggs. In the frog Electonotus pygmaeus, the eggs are carried on the back and covered with dorsal latero-frontal skin. The edges of the folds meet on the dorsal midline, forming a pocket.

In Gastrotheca, the two lobes are welded, forming a real brood pocket opened by a posterior orifice more or less close to the cloacal orifice [41]. In Assa darlingtoni (Australia), lateral incubators pockets were observed in males. Larvae can complete their development in ponds (Gastrotheca marsupiata). In other species (Gastrotheca ovifera, G. Grismaldi, G. Ochoa, G. christiani), the development is direct and the completely metamorphosed young comes out of the brood pocket. In all cases, young animals exhibit an increase in respiratory surfaces through the formation of bell-shaped gills. In Pipa pipa, an aquatic anuran from South America, embryos are incubated in the maternal back, inside small individual alveoli. The embryos develop slowly, each in its lodge filled with a liquid emitted by the skin of the female. Gill-free tadpoles have a well vascularized tail that provides respiratory function. Young animals hatch after metamorphosis and leave their protective cavity [37,39].

In Rhinoderma darwinii of Chile, as soon as the embryos become mobile, the males seize them using their tongue and install them in their vocal bags the walls of which becoming highly vascularized and secreting a viscous liquid. After the metamorphosis, the tadpoles are expelled. The tadpoles of Rhinoderma rufum also begin their development in vocal bags but they are expelled before the end of this development [42]. In the Australian species Rheobatrachus silus considered extinct since 2001, the incubation took place in the stomach of the female which was subjected to prolonged fasting and gastric secretions of which were inhibited [43]. 


\section{International Journal of Zoology and Animal Biology}

\section{Viviparity}

Numerous caecilians species are viviparous [25]. The best-known viviparous species are Dermophis mexicanus and Gymnopis multiplicata from Central America [44] and Typhlonectes compressicauda from South America [45]. In T. compressicauda, the wall of the oviduct is enlarged at the time of reproduction, becoming ciliated and secretory. Both the middle and posterior parts of oviduct constitute the uterus, also secretory $[31,45]$. The embryo, first protected by a gangue, is not in direct contact with the uterine lumen and develops from the yolk. After hatching, it feeds on the secretions of the oviduct wall through the fetal dentition. It even ends up tearing out the epithelial cells. In the end, the connective tissue remains bare and contacts are established between this wall and the vesicular gills of the embryo. The embryo is surrounded by these gills, one arranged as a coat and the other as a hood, forming a cocoon-like structure closely applied against the uterine wall $[39,45]$. Relationships are established between the surface of the gills and the uterine connective tissue. Signs of oophagy and adelphophagy have been observed. In viviparous $D$. mexicanus and $G$. multiplicata, the gills remain filamentous, certainly playing a role in gas absorption and exchange $[33,44]$.

Among the urodelans, in Salamandra atra, at ovulation, the oocyte is surrounded by a gangue developed by the tubal glands. Only the head oocyte develops first from the yolk reserves and then from a uterine magma from the secretions of the tubal wall mixed with more or less degraded abortive oocytes releasing yolk platelets. After depletion of these reserves, the uterine epithelium is responsible for granulation and the larva, with a fetal dentition, feeds on the secretions of the cell walls that regenerate when it moves [16]. The pregnancy can last four or five years. In Salamandra salamandra, embryos develop in oviducts. The tubal epithelium varies little and the epithelial cells ensure the regulation of the intrauterine fluid [46-49]. Other salamanders such as Mertensiella genus of Central and Eastern Europe can also be viviparous [48].

In the Anuran viviparous Nimbaphrynoides (Nectophrynoides) occidentalis, the uterus undergoes a succession of changes. The embryos bathe in a uterine fluid that they absorb orally [50-52].

\section{Direct Development}

In direct development, the eggs hatch from a metamorphosed animal. Such types of development are observed in Anurans (Nectophrynoides, Eleutherodactylus). Characterized by an egg containing a large amount of yolk, their development is reminiscent of that of most teleost fish. This type of development is also found in several caecilians such as Boulengerula taitanus $[35,36]$.

\section{Parental Care in Caecilians}

It is now well-know that a parental care exists in caecilians. In oviparous species such as Ichthyophis sp., the eggs are protected by the female which surrounds itself around the clutches of eggs. In several species, the young animals feed on the secretions emitted by the maternal skin (Schistometopum thomense, Boulengerula taitanus, Sipohnops annulatus) [53-58].

\section{Conclusions}

Amphibians are particularly sensitive to external factors. Consequences are observed on several aspects of their biology, and more particularly on the modes of reproduction. Sexual cycles are closely linked to seasonal alternation. In gymnophionans (caeciliians), internal fertilization is the rule and several species are viviparous. Male sexual cycles are generally discontinuous in species living in Asia and Central and South America; in some African species, the cycles are continuous. The female sexual cycles correspond to those of the males, and they are biennial in several viviparous species. In urodelans, fertilization can be indirectly internal. The cycles of males and females are discontinuous. In anurans, males and females cycles can be continuous or not, narrowly linked to the variations of temperature or rainfalls. In areas with regular seasonal variations, cycles are discontinuous. In areas with irregular rainfalls, cycles are continuous and the animals are ready to breed when external conditions are adequate.

In addition, amphibians which are necessarily subservient to the aquatic environment for reproduction, can present a wide panel of adaptations, both in their physiology and ecology. They can be oviparous or viviparous with several modes of maternal-fetal 


\section{International Journal of Zoology and Animal Biology}

exchanges. They can perform strange patterns of development like different marsupial forms of reproduction. These strange modes of reproduction have certainly contributed first to the conquest of the terrestrial environment and second to maintain themselves in this new environment with sometimes returns to the aquatic life.

Variations in reproduction may be certainly genetic and / or adaptive. An example can be given. In the natural environment, the sexual cycle of Typhlonectes compressicauda is closely related to seasonal alternation with breeding during the rainy season and quiescence during the dry season [29]. If animals are raised under artificial conditions in which they are still immersed in water, without a dry season, the male cycles remain the same, so this cycle is probably regulated by a molecular clock, a genetic factor. On the contrary, female cycles are deeply disturbed: vitellogenesis and ovulation are staggered [59]. In this case, the cycle is certainly more subject to external factors than the male cycle, and represents mainly an adaptation to the environment, with the intervention of epigenetic factors.

So, the sexual patterns of amphibians are particularly plastic, and they represent certainly an advantage for the conquest of terrestrial life. This conquest will be carried out by the reptiles, the first amniotes whose mode of reproduction involves a specialization, the amnion, allowing the embryo to remain maintained in an aquatic environment throughout its development, whatever it is.

\section{References}

1. Needham J (1959) A history of embryology. Cambridge University Press, Cambridge, UK.

2. Exbrayat JM, Moudilou EN, Abrouk L, Brun C (2012) Apoptosis in amphibian development. Advances in Bioscience and Biotechnology 3(6A): 669-678.

3. Briggs R, King JT (1951) Transplantation of living cell nuclei from blastula cells into enucleated frog's eggs. Proceedings of National Academy of Sciences of USA 38(5): 455-463.

4. Devillers J, Exbrayat JM (1992) Ecotoxicity of chemicals to Amphibians. Handbooks of ecotoxicological data, Gordon and Breach Science Publishers, Philadelphia, Reading, Paris, Montreux, Tokyo, Melbourne.
5. Gomes A, Giri B, Saha A, Mishra R, Dasgupta SC, et al. (2007) Bioactive molecules from amphibian skin: their biological activities with reference to therapeutic potentials for possible drug development. Indian J Exp Biol 45(7): 579-593.

6. Brand GD, Santos RC, Arake LM, Silva VG, Veras LMC, et al. (2013) The skin secretion of the amphibian Phyllomedusa nordestina: a source of antimicrobial and antiprotozoal peptides. Molecules 18(6): 70587070 .

7. Vitt LJ, Caldwell JP (2009) Herpetology, an introductory biology of Amphibians and Reptiles, $\left(3^{\text {rd }}\right.$ Edn). Academic Press, New York, Oxford, Paris, San Diego San Francisco, Singapore, Sidney, Toronto.

8. Rastogi R, Rastogi LI, di Meglio M, di Fiore $M$, d'Aniello B, et al. (2002) Hormonal regulation of reproductive cycles in Amphibians. In: Heatwole $\mathrm{H}$ (Eds.), vol (6) Amphibien biology, Surrey Beatty and sons, Cipping Norton, Australia pp: 2045-2177.

9. Delsol M, Flatin J, Gueydan Baconnier M, Neyrand de Leffemberg F, Pujol P (1980) Effect of external factors on reproduction cycles in Batrachians [Action des facteurs externes sur les cycles de reproduction chez les Batraciens]. Bulletin de la Société zoologique de France 106(4): 419-431.

10. Delsol M (1986) The fundamental types of reproduction [Les types fondamentaux de la reproduction]. In: Grassé PP and Delsol M (Eds.), Traité de zoologie, XIV, fasc. 1B, Masson, Paris pp: 322-338.

11. Duellman W, Trueb L (1994) Biology of Amphibians. Johns Hopkins University Press, Maryland, USA.

12. Kisserli O, Moudilou E, Exbrayat JM (2017) Sexual cycle and seasonal expression of testosterone (T) in the testes of Sclerophrys mauritanica (Schlegel, 1841). African Journal of Herpetology 66(2): 106-121.

13. Kisserli O, Doumandji S, Exbrayat JM (2011) Reproductive cycles in Bufo regularis (Schlegel, 1841) of wet area of Beni-Belaïd (Jijel, Algeria). Basic and Applied Herpetology 25: 65-71.

14. Neyrand de Leffemberg F, Exbrayat JM (1987) Some aspects of the kinetics of spermatogenesis of the Rana esculenta complex as a function of temperature. [Quelques aspects de la cinétique de la spermatogenèse du complexe Rana esculenta en 


\section{International Journal of Zoology and Animal Biology}

fonction de la temperature]. Bulletin de la Société herpétologique de France 41: 17-20.

15. Neyrand de Leffemberg F, Exbrayat JM (1991) Influence of temperature on the kinetics of spermatogenesis in Rana esculenta and Rana lessonae in July. [Influence de la température sur la cinétique de la spermatogenèse chez Rana esculenta et Rana lessonae en juillet]. Bulletin de la Société herpétologique de France 57: 31-40.

16. Neyrand de Leffemberg F, Exbrayat JM (1995) Comparative study of spermatogenesis in Amphibians using the histo auto radiographic method with tritiated thymidine. [Etude comparative de la spermatogenèse chez les Amphibiens par la méthode histoautoradiographique à la thymidine tritiée]. Bulletin de la Société linnéenne de Lyon 64(8): 356372.

17. Pujol P, Exbrayat JM (1993) and continuous sexual cycle in Bufo regularis Reuss (1834), Tropical Anura Amphibian [Oviductes et cycle sexuel continu chez Bufo regularis Reuss (1834), Amphibien Anoure tropical]. Bulletin de la Société zoologique de France 118(3): 361.

18. Vilter V (1986) The reproduction of the black salamander [La reproduction de la salamandre noire]. In: Grassé PP, Delsol M (Eds.), Traité de Zoologie, XIV, fasc. I B. Masson, Paris pp: 487-495.

19. Andreone F (1992) Observations on the territorial and reproductive behaviour of Salamandra lanzai and considerations about its protection (Amphibia: Salamandridae). British Herpetological Society Bulletin 39: 31-33.

20. Miaud C, Andreone F, Riberon A, de Michelis S, Clima $\mathrm{V}$, et al. (2001) Variations in age, size at maturity and gestation duration among two neighbouring populations of the alpine salamander (Salamandra lanzai). Journal of Zoology London 254(2): 251-260.

21. Yartsev VV, Exbrayat JM, Kuranova VN (2015) (in Russian) Oogenesis in the Siberian salamander, Salamandrella keyserlingii (Amphibia: Caudata, Hynobiidae). Tomsk State University Journal of Biology 4(32): 127-144.

22. Vadim VY, Valentina NK, Galina SM (2016) The male urogenital system of the Siberian salamander Salamandrella keyserlingii (Caudata: Hynobiidae) with special reference to the microstructure of the testes and sperm transport complex. Russian Journal of Herpetology 23(1): 1-6.

23. Yartsev VV, Exbrayat JM, Kuranova VN (2017) Spermatogenesis in the Siberian salamander Salamandrella keyserlingii (Caudata, Hynobiidae). Salamandra 53(1): 66-76.

24. Yartsev VV, Exbrayat JM, Kuranova VN (2018) Oviduct, egg, and egg sac structures in the Siberian salamander, Salamandrella keyserlingii (Caudata, Hynobiidae): a histological and histochemical study. Russian Journal of Herpetology in press.

25. Taylor EH (1968) The Caecilians of the world: A taxonomic review. University of Kansas Press, Lawrence, Kansas, USA.

26. Wake MH (1968) Evolutionary morphology of the Caecilian urogenital system. Part I: The gonads and fat bodies. J Morphol 126(3): 291-332.

27. Wake MH (1970) Evolutionary morphology of the caecilian urogenital system. Part II: The kidneys and urogenital ducts. Acta Anat (Basel) 75(3): 321-358.

28. Wake MH (1981) Structure and function of the male Mullerian gland in Caecilians (Amphibia: Gymnophiona), with comments on its evolutionary significance. Journal of Herpetology 15(1): 17-22.

29. Exbrayat JM (1985) Cycle of Müllerian duct in the adult male of Typhlonectes compressicaudus (Duméril and Bibron, 1841), Apodan Amphibian [Cycle des canaux de Müller chez le mâle adulte de Typhlonectes compressicaudus (Duméril et Bibron, 1841), Amphibien Apode]. Comptes-rendus des Séances de l'Académie des Sciences de Paris 301: 507-512.

30. Exbrayat JM, Estabel J (2006) Anatomy with particular reference to the reproductive system. Exbrayat JM, Estabel J (Eds.), Reproductive Biology and phylogeny of Gymnophiona (Caecilians), Science Publishers Inc, Enfield, Jersey pp: 79-155.

31. Exbrayat JM (2006) Endocrinology of reproduction. Exbrayat JM (Edn), Reproductive Biology and Phylogeny of Gymnophiona (Caecilians). Science Publishers Inc, Enfield, Jersey Pp: 183-229.

32. Exbrayat JM, Delsol (1985) Reproduction and growth of Typhlonectes compressicaudus, a viviparous Gymnophione. Copeia 1985(4): 950-955. 


\section{International Journal of Zoology and Animal Biology}

33. Wake MH (1980) Reproduction, growth and population structure of the Central American Caecilian Dermophis mexicanus. Herpetologica 36(3): 244-256.

34. Measey GJ, Smita M, Beyo RS, Oommen OV (2008) Year-round spermatogenic activity in anoviparous subterranean caecilian, Boulengerula taitanus Loveridge 1935 (Amphibia Gymnophiona Caeciliidae). Tropical Zoology 21: 109-122.

35. Raquet M, Measey GJ, Exbrayat JM (2015) Annual variations of ovarian structures of Boulengerula taitanus (Loveridge, 1935), a Kenyan caecilian. African Journal of Herpetology 64(2): 116-134.

36. Malonza PK, Measey GJ (2005) Life history of an African caecilian: Boulengerula taitanus Loveridge 1935 (Amphibia Gymnophiona Caeciilidae). Tropical Zoology 18: 49-66.

37. Lehtinen R, Nussbaum R (2003) Parental care: a phylogenetic perspective. Jamieson B, et al. (Eds.), Reproductive Biology and Phylogeny of Anura. Science Publishers Inc, Enfield, Jersey pp: 343-386.

38. Hraoui Bloquet S, Exbrayat JM (1993) Fertilization in Typhlonectes compressicaudus (Duméril and Bibron, 1841), Amphibia Gymnophiona [La fécondation chez Typhlonectes compressicaudus (Duméril et Bibron, 1841), Amphibien Gymnophione]. Bulletin de la Société zoologique de France 118: 356-357.

39. Exbrayat JM (2006) Fertilization and embryonic development. Exbrayat JM (Eds.), Reproductive Biology and Phylogeny of Gymnophiona. Science Publishers Inc, Enfield, Jersey pp: 359-386.

40. Lamotte M, Lescure J (1977) Adaptive trends in aquatic release in Anura Amphibians [Tendances adaptatives à l'affranchissement du milieu aquatique chez les amphibiens anoures]. Terre et Vie 31:225312.

41. Formas RE, Pugin E, Jorquera B (1975) The identity of the Chilean batrachians Heminectes rufus Philippi, 1902. Physis (Sección C) 34: 147-157.

42. Delpino EM, Galarza ML, Albuja CM, Humphries AA (1975) The maternal pouch and development in the marsupial frog Gastrotheca riobambae (Fowler). Biological Bulletin 149(3): 480-491.
43. Tyler MJ, Carter DB (1981) Oral birth of the young of the gastring brooding frog Rheobatrachus silus. Animal Behavior 29(1): 280-282.

44. Wake MH (1977) The reproductive biology of Caecilians: An evolutionary perspective. The Reproductive Biology of Amphibians, Miami Univ, Oxford, Ohio pp: 73-101.

45. Exbrayat JM, Hraoui-Bloquet S (2006) Viviparity in Typhlonectes compressicauda. Reproductive Biology and Phylogeny of Gymnophiona. Science Publishers Inc, Enfield, Jersey pp: 325-357.

46. Joly J (1986) The reproduction of the terrestrial salamander. [La reproduction de la salamandre terrestre]. In Grassé PP, Delsol M (Eds) Traité de Zoologie, XIV, fasc. I B. Masson, Paris pp: 471-486.

47. Greven H (1980) Ultra structural investigations of the epidermis and the gill epithelium in the intrauterine larvae of Salamandra salamandra (L.) (Amphibia, Urodela). Z Mikrosk Anat Forsch 94(2): 196-208.

48. Greven H (2003) Larviparity and puerparity. Reproductive Biology and Phylogeny of Urodela. Science Publishers Inc, Enfield, Jersey pp: 447-475.

49. Greven H, Guex GD (1994) Structural and physiological aspects of viviparity in Salamandra salamandra. Mertensiella 4: 139-160.

50. Xavier F (1977) An exceptional reproductive strategy in Anura: Nectophrynoides occidentalis Angel (Bufonidae). Major patterns in vertebrate evolution, Plenum Press, New York, USA pp: 545-552.

51. Xavier F (1986) The reproduction of Nectophrynoides [La reproduction des Nectophrynoides]. Traité de Zoologie, XIV, fasc. I B. Masson, Paris pp: 497-513.

52. Wake MH (1980) The Reproductive Biology of Nectophrynoides malcolmi (Amphibia: Bufonidae), with Comments on the Evolution of Reproductive Modes in the Genus Nectophrynoides. Copeia 1980(2): 193-209.

53. Kupfer A, Müller H, Antoniazzi MM, Jared C, Greven H, et al (2006) Parental investment by skin feeding in a caecilian amphibian. Nature 440(7086): 926-929.

54. Kouete MT, Wilkinson M, Gower DJ (2012). First reproductive observations for Herpele Peters, 1880 (Amphibia: Gymnophiona: Herpelidae): evidence of 


\section{International Journal of Zoology and Animal Biology}

extended parental care and maternal dermatophagy in Herpele squalostoma (Stutchbury, 1836). International Scholarly Research Notices 2012: 7.

55. Wilkinson M, Sherratt E, Starace F, Gower DJ (2013) Anew species of skin-feeding Caecilian and the first report of reproductive mode in Microcaecilia (Amphibia: Gymnophiona: Siphonopidae). PLoS One 8(3): e57756.

56. Wilkinson M, Kupfer A, Marques Porto R, Jeffkins H, Antoniazzi MM, et al. (2008) One hundred million years of skin feeding? Extended parental care in a neotropical caecilian (Amphibia: Gymnophiona). Biol Lett 4(4): 358-361.

57. Kupfer A, Wilkinson M, Gower DJ, Müller H, Jehle R (2008) Care and parentage in a skin-feeding caecilian amphibian, J Exp Zool A Ecol Genet Physiol 309(8): 460-467.

58. Jared C, Mailho Fontana PL, Jared SGS, Kupfer A, Delabie JHC, et al. (2018) Life history and reproduction of the neotropical caecilian Siphonops annulatus (Amphibia, Gymnophiona, Siphonopidae), with special emphasis on parental care. Acta Zoologica. In press.

59. Exbrayat JM, Laurent MT (1986) Some observations on reproduction in breeding Typhlonectes compressicaudus, a viviparous Amphibian Apodan. Possibility of endogenous rhythms [Quelques observations sur la reproduction en élevage de Typhlonectes compressicaudus Amphibien Apode vivipare. Possibilité de rythmes endogènes]. Bulletin de la Société herpétologique de France 40: 52-62. 